\title{
БОТАНІЧНІ НАЗВИ НА -ОК У КОНФІКСАЛЬНІЙ ПІДСИСТЕМІ УКРАЇНСЬКОГО ІМЕННИКА
}

Качайло К. А. Ботанічні назви на -ок у конфіксальній підсистемі українського іменника.

У статті розглянуто особливості словотвірної структури і семантики ботанічних назв на -ок та з'ясовано їх місце в конфіксальній підсистемі українського іменника. Вивчено активність конфіксів, зокрема формантів з постпозитивним компонентом -ок, у процесі творення найменувань рослин.

Ключові слова: конфікс, словотвірна структура, фітонім.

Качайло К. А. Ботанические названия на -ок в конфиксальной подсистеме украинского имени существительного.

В статье рассмотрены особенности словообразовательной структуры и семантики ботанических названий на -ок и установлено их место в конфиксальной подсистеме украинского имени существительного. Изучена активность конфиксов, конкретно формантов с постпозитивным компонентом -ок, в процессе образования наименований растений.

Ключевые слова: конфикс, словообразовательная структура, фитоним.

Kachaylo K. A. Botanical names on -ok in the confixes subsystem of the Ukrainian nouns.

The features derivational structure and semantics of botanical names on -ok were reviewed in the article and their place in the confixes subsystem of the Ukrainian nouns was determined. The activity of confixes was leant, specifically formants with the postpositive component - ok in the formation process of the botanical names.

Key words: confixes, derivation structure, fiton.

Назви рослин належать до найбільших і найдавніших пластів лексики української мови. Вони неоднорідні за сферою вживання. Досить чітко на сьогодні виділяються дві основні, тісно взаємопов'язані групи: діалектні і літературні найменування рослин, які містять певні фонетичні, словотвірні та морфологічні особливості. Це викликає до них інтерес з боку дослідників мови, які й вивчають фітоніми в різних аспектах. Відомі праці таких учених, як: В. Л. Карпова, Т. Я. Марченко, Л. Москаленко, І. В. Сабадош, Л. О. Симоненко, Л. Д. Фроляк та інші. Оскільки назви рослин, маючи різноманітну словотвірну структуру та специфічну семантику, включають i конфіксальні деривати, на нашу думку, є доречним вивчення таких ботанічних найменувань. 
Мета роботи - 3'ясувати особливості словотвірної структури i семантики ботанічних назв на -ок та їх місце в конфіксальній підсистемі українського іменника.

Як зазначено в сучасній науковій літературі, “конфіксальні найменування рослин, за даними реконструкцій, були в праслов'янській мові (*nedotyka "рослина Impatiens nolime tangere", *отапь "бот. Inula L.; дивина чорна", *snětъ ( "snětb) "бот. сажка", *šadbra "назва рослини; шлях, дорога" *obbabъkъ "гриб підберезник”, *medjipbrstbnica / *medjupbrstbnica “нагноєння між пальцями; рослина Trifolium lupanaster L.”). У давній руськоукраїнській мові ботанічних номенів зафіксовано небагато: пародникъ "кислий, недозрілий плід”, озимица “озимий хліб, озимі посіви”. Середньоукраїнські пам'ятки також документують невелику кількість назв рослин: припоутникъ “лікарська рослина - подорожник”, подорожникъ, пародокъ “кислий, незрілий плід або відросток”, шзимина. У новій українській мові ботанічні найменування, утворені конфіксальним способом, фіксуються значно частіше" [1, с. 362].

За даними нашого дослідження, конфіксальні ботанічні назви на -ок наявні в пам'ятках з XVII століття, і в подальшому їх нараховується небагато (близько сорока іменників). До утворення назв рослин та їх частин, а також грибів залучено більше десяти конфіксів 3 другим компонентом -ок, а саме: під-..-ок, полу-..-ок, при-..-ок, o-..-ок, na-... -ок, по-...-ок, від-...-ок, су-..-ок, на-...-ок, про-...-ок, роз-...-ок.

Із формантом nid-...-ок наявні номени рослин за місцем, де вони ростуть, зокрема під тим, що названо вивідним словом: підлісок (1874 Рогович 157; 2005 СГГ 139) “лісова фіалка або духмяна фіалка”; піддубок (Гр III 165; 1924 Кр I 344) “вид грибів, які ростуть у дібровах” або “піддубник” (СУМ VI 425); під’ясминок (1928 Бот 243) “вид пахучої рослини, яка росте під кущем і подібна до ясмина"; підгрибок (1965 ГорбачРоманів 70) “гриб моховик”; підсмерічок (1984 О II 71) “вид грибів, які ростуть біля смерек”; підгруздок (СУМ VI 420) “істівний гриб, схожий на груздь"; підлісок (СУМ VI 450) "кущі та зовсім молоді дерева, що ростуть у нижньому ярусі, у нижній частині лісу"; підтравок (СУМ VI 516) "невисока трава, що росте серед вищої частини травостою, рідше серед злаків"; підпеньок (2000 СЗГ ІІ 50) “опеньок”, пітпінок (2003 УГР 683) та пітпеньок (2005 СГГ 140).

Порівняймо найменування рослин, які утворені за допомогою інших конфіксів та мають таке ж словотвірне значення. За допомогою морфеми nid-...-ник, на думку сучасних вчених, утворилися фітоніми підлистник "копитняк європейський”, підорішник та підгорішник “копитняк", підсніжник, підсонічник "соняшник", підтинник, підбережник, niддубрівник "айстра степова", підгайник "кінський часник черешковий”, nідлесник "копитняк європейський", підгорошник "вероніка колосиста" тощо [1, с. 214]. Окрему підгрупу складають мікологічні назви: підолішник, 
підолишник та подолешник “гриб, що росте під ольхою”, піддубник та піддубеньник “їстівний гриб, схожий на боровик”, підосинник “гриб, що росте під осикою”, підберезник “один із їстівних грибів із бурою шапинкою та білим м'якушем, що росте переважно в березових лісах”, підсливник “їстівний гриб, який росте переважно під фруктовими деревами", підлісник “гриб, що росте під лісом", підтопілник “гриб, що росте під тополею; істівний 3 коричнево-червоною шапочкою” та ін. [1, с. 214-215]. Формант nid-...-ень також бере участь у творенні відіменникових назв грибів: піддубень "гриб, що росте під дубом", niдгруздень, підлистень [1, с. 339]. Цікавими за семантикою є деривати із конфіксом під-...-(н)иця: підкрапивниця “суниці зелені” [1, с. 299] та під-...ø: підвищень “гриби, що ростуть від вишнями”, подгреб “гриби, які ростуть під грабами” [1, с. 196].

Із кінця XIX століття спорадично засвідчуються назви рослин та їх частин, утворені за допомогою конфікса при-...-ок, наприклад: припупок (1879 Павл 902) “маленький пупок на рослині біля великого”; прицвіток (1927 ПТ 223) “маленький листочок, що міститься під квіткою біля цвіту”, “листок, з пазухи якого виходять квітки” (СУМ VIII 91); прибруньок (1931 СгТ 69) “додаткова брунька, що знаходиться біля головної”; прикоренок (СУМ VII 644) “частина стовбура коло кореня”, “нижня, коротка частина стовбура, спиляного чи зрубаного при корені дерева” (2004 Матіїв 19); прилисток (СУМ VII 659) “листоподібний паросток, що міститься біля основи листка"; припеньок (2000 СЗГ II 88) “опеньок”.

Описані деривати утворювалися після деяких похідних слів i паралельно з іншими конфіксальним ботанічними найменуваннями, які так само називають рослини (або їх частини), що ростуть біля чогось, позначеного твірним словом. Серед них відомі фітоніми 3 формантами при-..-ник, при-..-ень, при-..-б, при-..-(н)иця, наприклад: припутник “подорожник великий, піщаний, середній”, прицвіточник, придорожник “подорожний великий" або "цикорій”, приболотник “гадючний в'язолистий”, притрутник, принасінник “невеликі вирости на насінні деяких рослин”, прибережник “морська трава”, приберезник “підберезник” [1, с. 229]; припутень "подорожник", прикорень “частина кореня або стебла трав'янистої рослини біля кореня" [1, с. 340]; присада “рослина”, присторч "гострий пеньок молодого дерева" [1, с. 189], прибережниця “багаторічна рослина родини злакових" [1, с. 298].

Досить пізно, за даними фактичного матеріалу, фіксуються ботанічні номени 3 конфіксом $о$-...-ок та назви їх частин за місцем розташування (навколо того, що назване вивідним словом): опенокъ (1840 Б-Н 263) “гриб, який росте біля пня, підпеньок”, опеньок (1918 ІвШум 83) “шапинковий базидіальний гриб 3 порядку гіменоміцетів родини пластинчастих, їстівний” або “їстівний гриб $з$ жовтуватою шапинкою на тонкій високій ніжці, що звичайно росте купками на пеньках та біля 
коренів дерев” (СУМ V 704); окоренок (Гр III 49) “частина стовбура дерева від коріння до гілок”, “низ снопа без колосся” (2000 СЗГ II 12); очашок (1931 СгТ 66) “ботанічна назва: те у структурі квітки, що знаходиться під чашкою, прилягає до неї”.

Очевидно, доречно згадати й інші фітоніми, які утворені за допомогою різних конфіксів із препозитивною частиною $o$ - та словотвірним значенням “те, що розташоване навколо або біля чогось, названого твірною основою”. Наприклад, деривати 3 афіксами $о$-...-ник (опоясник “зілля, яким уперізують мов поясом на щастя, щоб з'єднати прихильність любих собі осіб", омежник “те, що росте на межі", оводник “рослина, яка росте біля води”, окривавник “звіробій” [1, с. 244]), о-..-ø (оман “дивина чорна”, оплавы “водяні рослини”, огарь “обгорілий пеньок”, осока, осіка та осіч "багаторічна болотна трава родини осокових 3 довгими гострими листками” [1, с. 165], озимъ “озимий хліб, який сіють восени на полях, зораних влітку”, окіст “шавлія ефіопська”, [1, с. 169-170]), o-...-ина (озимина, оцвітина "зовнішня частина квітки, що оточує тичинки й маточку", осмолина “смолисте дерево”, опашина “отава; паша" [1, с. 304]), o-...-(')aк (оситняк “багаторічна або однорічна рослина родини ситникових, схожа на очерет" [1, с. 342]).

Іменники 3 морфемою $н a-\ldots-о к$ називають рослини та їхні частини: накоренок (1886 Ж 480) “відросток на корені”, “нижня, коротка частина стовбура, спиляного чи зрубаного при корені дерева” (2004 Матіїв 19); навраток, навороток (1912 Верх 253) "народна назва ранника, пижма звичайного” пов'язане 3 праслов'янськими основами *vert-/vort“повертати”, пор. сучасне вороття "повернення", назва зумовлена здатністю рослини повертати, втрачена неповноголосна форма, певне, - запозичення 3 діалектів чеської чи словацької мови (див. ЕСУМ IV 14, 19); намулок (1922 Мельник 103) "рослина, що росте біля річок, ставів, на болотах, рідше на степу”; наголоваток (1922 Мельник 72) “будяк, волошки”.

Деривати зі словотвірним значенням “те, що розташоване на чомусь, названому твірною основою” утворюються також за допомогою конфіксів

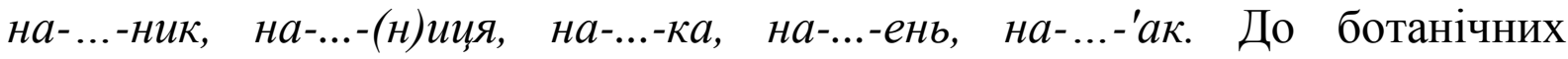
найменувань належать такі: напутник "подорожник великий”, насонішник “соняшник” (тут можливий універбаційний процес: похідне могло утворитися від сполуки “рослина, що повертається на сонячний бік”), пор. насонник “соняшник” від сонце, 3 відтинанням суфіксального -uз-; насонешник, насердник "рослина, за допомогою якої лікуються хвороби серця", насмітник “рослина, яка росте на смітнику”, насілник “старий огірок, який ішов на соління", наворотник "рослина 3 властивістю допомагати щасливому поверненню додому подорожніх", натресник “конюшина шарудлива”, натошник “м'ята перцева” [1, с. 237], насмітниия “рослина, що росте на смітнику”, настеблиияя “медова трава шерстиста” 
[1, с. 294-295], наземка “рослина, яка росте при землі” [1, с. 326], наголоватень “волошка" [1, с. 339], наконешняк “китичник” [1, с. 342].

Iз XVII століття 3 конфіксом na-..-ок засвідчено найменування рослин, які не повною мірою виявляють ознаки певних видів представників флори і становлять окремий підвид: пародокъ (1627 БерЛекс 80) “кислий, незрілий плід або відросток" (родъ “природна властивість; сукупність предметів із загальними головними ознаками"); паріпок (1886 Ж 602) “жовтушник дрібноцвітний, свиріпка” (ріпа “вид рослин”); падубок (1952 Мельн 142) “кущ або деревце до 4 метрів височиною”; пакленок (1994 Смик 122) “клен польовий, вид рослин із родини кленів”, памолодок (2000 СЗГ II 25) “пагін дерева; молода гілка".

Відомі ще ботанічні назви, утворені за допомогою лише одного конфікса із першою частиною $n a$ - та матеріально невираженою постпозитивною частиною. Наприклад: пагін "молода гілка або стеблина рослини", napicmb, napocms та napocm "молода гілка або стеблина рослини”, патик “тверда частина пір'їни”, павис “аномодон” [1, с. 191192], павороз “чіпкий пагін у деяких рослин, за допомогою якого вони плетуться" від вороза “мотуз, шнурок”, паросль “молодий ліс", пасердя “серцевина, внутрішня частина стовбура дерева”, пазелень та памолодь “молоді пагони; поросль молодих дерев”, палуза, палюза “довга тонка гілка верби або іншого дерева" (лоза, лозина) [1, с. 192-193].

Із формантом за-..-ок зафіксовано найменування рослин, які за деякими ознаками подібні до тих, що називає твірна основа: закомелок (1879 Павл 259) “рослина з виду камелій”; завербок (1984 О I 261) “червона верба"; а також назву частини рослини: закоренок (1886 Ж 250; 2000 ГГ 278) “частина стовбура дерева, що розташована коло кореня”.

Порівняльний аналіз дозволяє стверджувати, що найбільше ботанічних назв серед конфіксальних утворень 3 препозитивною частиною за- 3 афіксом за-...-ник, наприклад: заболоточник "оман британський” (рослина росте на мокрих луках, по полях, степах, при берегах потоків, в ровах), заграничник та заграницьник “галінсога дрібноцвіта", назва зумовлена тим, що рослина занесена з-за кордону (з Свропи), куди вона потрапила на початку XIX століття 3 Америки; загнітник “пароніхія головчаста", пов'язане з загнітниця “нігтьоїда, нарив на пальці під нігтем" (загнітиия - результат видозміни форми занігтиця під упливом гнітити “давити, тиснути”); залучник (рослина росте коло хат, плотів, звичайний бур'ян), завербник “верба біла” або “кущі, місце за вербами”, загайник “посадка молодого лісу”, закомірник "шипшина”, зашорник “фіалка триколірна”, задвійник “зозулині сльози яйцелисті”, зав'язник “перстач прямостійний, калган” [1, с. 231-232]. Наявні також поодинокі деривати 3 формантами за-...-ø та за-...-иця, наприклад: заверба "рід рослин із породи Salix" [1, с. 175], загнітиця “скребниця аптечна” [1, с. 298]. 
Конфікс про-..-ок бере участь у творенні окремих сучасних найменувань рослин, наприклад: пролісок (Кв-Осн III 45) “різновид трав'янистої рослини родини лілійних з блакитними чи синіми квітками, які ростуть на лісових галявинах"; просуренок (1922 Мельник 89) “шафран сорокатий, народна назва рослини" або “біла, з фіолетовими прожилками квітка, надзвичайно приємного запаху, яка розквітає раніше проліска” (2002 СУСГ 178), також просурок (2002 СУСГ 178) “пролісок” (серен, сирен, сурен "наст, обледеніла кірка на поверхні снігу, що утворюється від посилення морозу після відлиги”), пор. назву явища природи просуренок (1984 ДзПА 266) “іній, ожеледь”. Цікаво, що за допомогою конфікса про-...-ка утворюється іменник проліска [1, с. 329], який є паралельною назвою до пролісок.

За нашими даними, зрідка фіксуються пооодинокі назви рослин або їх частин з морфемами су-...-ок (суріпок (1922 Мельник 53) "рослина, яку плекають із насіння, з якого добувають олію” (ріna “вид рослин”, синонім до рипій або біла ріпа); роз-...-ок (розкорінок (1927 ПТ 228) “частина дерева, що знаходиться в землі і має розгалужену форму”); по-...-ок (покоренок (1886 Ж 685) “частина стовбура біля дерева”); полу-...-ок (полуц̧віток (1994 Смик 133) “фіалка триколірна”).

Однак із конфіксами, які мають згадану препозитивну й іншу постпозитивну частину є досить багато ботанічних назв. Форманти $n o-. .$. -ник, по-...-(н)иця, по-...-ка, по-...-б наявні у найменуваннях рослин, які ростуть біля того, що названо вивідним словом: подорожник, подоріжник та подорижник “трав’яниста лікарська рослина 3 широким смугастим листям”, “спориш”, “мох” пор. поранник “подорожник” (прикладається до рани); попутник "первоцвіт весняний”, порічник, побережник; посоняшник, посонічник, посонячник “соняшник”; поручейник, потайник [1, с. 225], поземка "суниці лісові” [1, с. 322], потрост “бічні пагони на стеблі рослини”, потрав “отава, трава, що виросла в той же рік на місці скошеноі” [1, с. 161], а також - у фітонімах, які утворені на основі зовнішньої подібності до того, що назване вивідним словом: помолочник "рослина, сік якої нагадує молоко"; побородник; покоронник "рослина, формою подібна до корони"; поральник "рослина, за формою схожа на рало" [1, с. 225], повитиця “витка без коренів, паразитична однорічна трав'яниста рослина", пор. діалектний варіант повитницяя “те саме" від витися або повитися [1, с. 296].

Кілька дериватів містять у словотвірній структурі конфікси $c y-\ldots$ - ja,

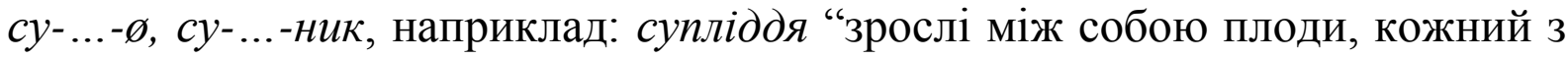
яких утворився 3 окремої квітки щільного суцвіття”, суц̧вітmя “квітконосне стебло разом із пуп'янками і квітками, зібраними у вигляді китиці, парасольки, кошика, колоса" [1, с. 144], сумісь, суміш “мішаний ліс", суволока "різновид бур'яну; пирій” [1, с. 178], суягідник "шовковиця" $[1$, c. 222]. Неповноту вияву названої твірним словом ознаки ілюструє 
сучасний ботанічний номен полуиявітка, утворений за допомогою конфікса полу-...-ка [1, с. 327].

Варто зазначити, що частина конфіксальних найменувань рослин утворена за допомогою цілого ряду словотвірних засобів, які по-різному виявляють свою продуктивність. На думку сучасних вчених, активними виявились конфікси без-...-ник, без-..-б, без-...-(н)иия, без-..-ка, не-..-б, не-...-ка, про що свідчать такі деривати, як: без'язичник “заспокійливе зілля"; безслинник "паслін чорний”; безсмертник "рослина, яка, засихаючи, довго зберігає вигляд свіжих квітів"; безвершник “талабан польовий"; безвременник "пізньоцвіт осінній”; безщзитник "рід папоротей 3 родини багатоніжкових"; безлистник “агалик - трава гірська" [1, с. 220]; безлисть “хвощ”, безияв tmb [1, с. 205]; безплідниця “рослина, яка не плодоносить", безстидниияя "суничник дрібноплодий” [1, с. 297]; безсмертка "те саме, що безсмертник"; безкорінка "сальвінія плаваюча" [1, с. 328]; нежар, нежерь, нежир “торішня трава, нез'їдена худобою, яка перезимувала на пні"; нелень, нелинь “дуб, з якого на зиму не опадає листя"; недогін, нидогони "поодинокі рослини, що відстали у своєму розвитку від загального масиву"; некіс "некошена смуга трави або збіжжя"; незахват "те саме"; негин "кукіль"; неруш; недотика, недотрога, недостуn "тамус звичайний”; нелин “кукіль звичайний”, нетронь "нетреба колюча" [1, с. 154]; незабудка, низабутька “трав'яниста рослина 3 дрібними блакитними; невійка “трясучка середня” [1, с. 323-324].

Решта формантів $\epsilon$ непродуктивними й виокремлюється у поодиноких прикладах: преріс “молоді пагони на місці зрізаних чи зрубаних", престурч “гострий пеньочок молодого дерева" [1, с. 188]; переполох “валеріана лікарська", перелаз “переступень білий”, перерва верболіззя лучне; цикорій дикий” [1, с. 201]; од’ядник “рослина, яка нейтралізує отруту”, откашльник “рослина, за допомогою якої лікують кашель” [1, с. 246]; переліска “лісова багаторічна трав'яна рослина з блакитними квітами” [1, с. 328]; меживузля та міжвузля "частина стебла між двома вузлами - місце прикріплення листя, а також пагінців, коренів" [1, с. 137].

Таким чином, ботанічні найменування, утворені конфіксальним способом, формують групу назв лікарських рослин, найменувань рослин за місцем їхнього розташування, конфіксальних назв грибів, а також назви дерев, кущів та їхніх частин. За даними фактичного матеріалу, ботанічні назви на -ок мають особливу семантику та словотвірну структуру i займають окреме місце у конфіксальній підсистемі українського іменника.

БерЛекс

Б-H

Бот

\section{Список використаних джерел}

Лексикон словенороський Памви Беринди / Підгот. тексту і вступ. стаття В. В. Німчука : Надрук. 3 вид. 1627 р. фотомех. способом. - К. : Вид-во АН УРСР, 1961. XL, 272 c.

Білецький-Носенко П. Словник української мови / П. Білецький-Носенко [підгот. до вид. В. В. Німчук]. - К. : Наукова думка, $-1966 .-423$ с.

Словник ботанічної номенклатури /Проєкт/. - К., 1928. - 313 с. 
Bepx

$Г Г$

ГорбачРоманів

$\Gamma \mathrm{p}$

ДзПА

ECYM

Ж

ІвШ

Кв-Осн

$\mathrm{Kp}$

Матіїв

Мельн

Мельник

O

Павл

ПТ

Рогович

СГГ

СгT

С $3 Г$

Смик

СУМ

ССУГ

УГР

Верхратський I. Знадоби до пізнання угорсько-руських говорів / I. Верхратський // Записки наукового товариства ім. Т. Шевченка. - 1899. - Т. 27-30; 1901. - Т. 40, 44; 1902. - T. 45.

Гуцульські говірки. Лінгвістичні та етнолінгвістичні дослідження / Відп. ред. Закревська Я. В. - Львів, 2000. - 364 с.

Горбач О. Північно-наддністрянська говірка й діялектний словник с. Романів Львівської обл. / О. Горбач. - Мюнхен, 1965. - 103 с.

Словарь української мови. Зібрала редакція журналу "Киевская старина" / Упорядкував з дод. власного матеріалу Б. Грінченко. - Т. 1-4. - К., 1907-1909.

Дзендзелівський Й. О. Програма для збирання матеріалів до лексичного атласу української мови / Й. О. Дзендзелівський. - К., 1984. - 308 с.

Етимологічний словник української мови / За ред. Л. С. Мельничука : у 7-и т. - Т. 15. - К. : Наукова думка, 1982-2006.

Желеховский Е. Малорусско-німецкий словар / Е. Желеховский. - Т. 1-2. - Львів, 1886. - 1117 c.

Іваницький С. Російсько-український словник / С. Іваницький, І. Шумлянський : у 2х т. - Липськ-Харків, 1925.

Словник мови творів Г. Квітки-Основ'яненка : у 3-х т. - Харків : ХДУ, 1978-1979. T. 1-3.

Російсько-український словник правничої мови / Гол. ред. А. Ю.Кримський. - К., 1926. - 228 c.

Матіїв М. Д. Методичні поради і матеріали для діалектологічної практики студентівфілологів / М. Д. Матіїв. - Сімферополь : Доля, 2004. - 79 с.

Мельничук О. С. Словник специфічної говірки села Писарівки (Кодимського району Одеської області) / О. С. Мельничук // Лексикографічний бюлетень. - Вип. 2. - К. : Вид-во АН УРСР, 1952. - С. 67-98.

Мельник М. Українська номенклатура висших ростин / М. Мельник. - Львів, 1922. $250 \mathrm{c.}$

Онишкевич М. Й. Словник бойківських говірок / М. Й. Онишкевич. - Ч. 1-2. К., 1984.

Павловскій А. Грамматика малороссійскаго нарьчія. Краткій малороссійскій словарь / А. Павловскій. - СПб, 1818. - 114 с.

Словник природничої термінології. - К., 1927. - 262 с.

Рогович А. С. Опыт словаря народных названий растений / А. С. Рогович. - К., 1874. $-59 \mathrm{c}$.

Піпаш Ю. О. Матеріали до словника гуцульських говірок (Косівська Поляна i Росішка Рахівського району Закарпатської області) / Ю. О. Піпаш, Б. К. Галас. Ужгород, 2005. - $266 \mathrm{c.}$

Сабалдир Г. О. Практичний словник сільськогосподарської термінології / Г. О. Сабалдир. - Харків, 1931. - 99 с.

Аркушин Г. Л. Словник західнополіських говірок / Г. Л. Аркушин : у 2-х т. - Луцьк : Редакційно-видавничий відділ “Вежа" Волинського державного університету ім. Лесі Українки, 2000.

Смик Г. К. Корисні та рідкісні рослини України : Словник-довідник народних назв / Г. К. Смик. - К., 1994. -412 с.

Словник української мови : у 11-и т. - К., 1970-1980. - Т. 1-11.

Глуховцева К. Словник українських східнослобожанських говірок / К. Глуховцева, В. Лєснова, І. Ніколаєнко, Т. Терновська, В. Ужченко. - Луганськ, 2002. - 234 с.

Павлюк М. Українські говори Румунії. Діялектні тексти / М. Павлюк, І. Робчук. Едмонтон-Львів-Нью-Йорк-Торонто, 2003. - 784 с.

\section{Література}

1. Білоусенко П. І. Нариси 3 історії українського словотворення (іменникові конфікси) / П. І. Білоусенко, І. О. Іншакова, К. А. Качайло, О. В. Меркулова, Л. М. Стовбур. - Запоріжжя - Кривий Ріг : ТОВ «ЛІПС» ЛТД, 2010. - 480 с.

2. Карпова В. Л. Староукраїнські вторинні назви рослин / В. Л. Карпова // Мовознавство. - 1984. № 2. - С. 46-54.

3. Марченко Т. Я. Типи словотвору українських і сербських назв рослин / Т. Я. Марченко // Актуальні проблеми українського словотвору : [Матеріали III-іх наукових читань, присв. пам'яті проф. Івана Ковалика]. - Івано-Франківськ, 1995. - С. 102-103. 
4. Москаленко Л. А. Ботанічні паралелі / Л. А. Москаленко // Культура слова. - К., 1990. - Вип. 39. - C. 70-74.

5. Москаленко Л. Подібність рослини до іншої рослини як джерело номінації / Л. Москаленко // Українська мова. - 2002. - №3. - С. 39-50.

6. Сабадош I. В. Збагачення складу ботанічної лексики староукраїнської мови / I. В. Сабадош // Українське мовознавство. - Вип. 16. - К., 1989. - С. 91-98.

7. Сабадош I. В. Народні назви рослин і наукова ботанічна номенклатура / I. В. Сабадош // Культура слова. - К., 1985. - Вип. 28. - С. 25-29.

8. Фроляк Л. Д. Тонколиста окраса степу / Л. Д. Фроляк // Культура слова. - К., 1989. - Вип. 36. - С. $79-81$. Стаття надійшла до редакції 24.10.2011 р. 